\title{
Anthropological Bases On The Path To the Sanctification Of Man*
}

The reality in which contemporary people live is a perfect space and as such it allows us to fulfill the everlasting inner desire to reach perfection. There is, however, a constant urge for answers regarding such matters as human nature, personality and subjectivity, and our relation to God, who is selfless Love. Other equally important aspects include the relation to other individuals, to ourselves and to the reality in which we live. These are the fundamental issues that influence the inner life of the human striving for perfection.

\section{Human Nature}

Touching upon the issue of the human pursuit of perfection, we face the question of the mere nature of humans and the nature of God with whom they wish to unite. Therefore, one of the fundamental matters of spiritual theology is the question: who is man? Any attempt to answer the question leads to multiple possibilities, because self-reflection is the object of constant examination ${ }^{1}$.

The very same question was posed at the Second Vatican Council in regard to issues and opinions stemming from the grounds of history of philosophy and religion. As we read in one of the constitutions that followed the Second Vatican Council: "But what is man? About himself he has expressed, and continues to express, many divergent and even contradictory opinions. In these he often exalts himself as the absolute measure of all things or debases himself to the point of despair. The result is doubt and anxiety" (GS 12).

STV 42(2004)1.

1 Cf. A. Słomkowski, Teologia życia duchowego, Ząbki 2000, 32; L. Borie, Giovanna della Croce, B. Second, in: Historia duchowości, Współczesność, vol. 6, Kraków 1998, 353 f. 
To answer this complex question fully, one needs to examine the relation between humans and God, the Creator who brought us into existence. To reach definite conclusions, it is crucial to address the question of human nature, in which humans are understood as the subject of spiritual life. Even a brief observation leads to the conclusion that humans are beings brought to life directly by God the Creator, and hence cannot think of themselves as a perfect being, an equal to God. Man is not an ultimate and completely independent being, which results from the simple fact of creation - being brought into existence - that aks questions of causality and purpose. Therefore, we experience the necessity of constantly referring to the authority of the One who conditioned our origins ${ }^{2}$. As Romano Guardini stated, the fact of humans originating from God does not threaten humans themselves in any way; on the contrary, it allows us to find the right image of the Creator and of ourselves ${ }^{3}$. This is how the process of putting human life in order happens. This means introducing harmony to our inner and outer life, a harmony that has been disturbed by sin (cf. GS 13).

Analysing human existence, we realize how complex it is. Apart from the material aspect of existence, a whole vast territory of spiritual life is called into question. Hence the constant attempts in the history of humankind to detach humans from identifying solely with the material world. One example of such an attempt is the Platonic system with its distrust towards the material world. Plato focused on detachment from materiality and his thought echoed in Saint Augustine's teachings, as well as in the early anthropological approach that developed within the Church in the first centuries $\mathrm{AD}^{4}$.

Throughout the history of this school of thought several opposing stances were formulated, pointing to empirical knowledge as the only source of truth ${ }^{5}$. Contemporary radical materialistic theories claim that matter, and that includes human, created the animate world in the process of development according to the rules of dialectics. According to these theories, the world is uniform, but matter is varied and divided into three categories: inanimate, animate and thinking matter. This explains why man is defined as thinking matter in Marxism. Therefore, it is materialistic monism ${ }^{6}$.

2 Cf. A. Słomkowski, op. cit., 33.

Cf. R. Guardini, Świat i osoba, Kraków 1969, 108.

Z. Targoński, Przesłanki antropologiczne duchowości, in: Teologia duchowości katolickiej, ed. W. Słomka, M. Chmielewski, J. Misiurek, A. Nowak, Lublin 1993, 85.

5 Por. W. Granat, Ku człowiekowi i Bogu w Chrystusie. Zarys dogmatyki katolickiej, vol. 1, Lublin 1972, 69.

6 Cf. S. Kowalczyk, Podstawy światopoglądu chrześcijańskiego, Lublin 1993, 33-38. 
Neither of the two gives a comprehensive answer to the question of human nature. They are partial descriptions, mere fragments that do not reflect man as a corporeal and spiritual being. The material and spiritual perspective places us in front of the subject of human's nature integrality ${ }^{7}$. The integrality of a human being was already reflected upon by Aristotle, who wrote about the relation between intelligence and human modality ${ }^{8}$. The matter was continued in the works of Saint Thomas Aquinas who pointed to the direct correlation between the human soul and body ${ }^{9}$. What is important is that the name human itself incorporates a statement of our grand nature (kataphasa). Observations and experience points to human limitations (apophasa). Human nature constantly develops integrity in this area (henozis). It is materiality (soma) with all its limitations and spirituality ( $p s y c h e$ ) as something completely opposite, immaterial, non-corporeal ${ }^{10}$. Defining these two ranges of human existence is crucial for spirituality, because of the constant necessity of introducing harmony between the two. As Bartnik wrote: "Man is split not only into two realms: of matter and spirit, earth and heaven, time and eternity; but also into two themes: existence and death, being and nothingness, affirmation and negation, identity and dispersion, values and anti-values. And at the same time human beings strive to overcome this opposition of structure and subject matter. Thereby, dialectics is the source of becoming, historicity, inconceivable possibilities and chances, of self-transcendence." who are brought to existence in order to constantly overcome barriers of materiality creates a sort of third dimension of human life. Anthropology cannot be narrowed down to a phenomenological approach. The grandeur of human nature keeps slipping out of man's control. It is important to emphasize the tragedy and the insufficiency of reductionist efforts in anthropological hermeneutics. Such as: man is an ape humanized by work (Friedrich Engels); an animal that builds tools (Benjamin Franklin); an animal with an erect walk

\footnotetext{
Cf. Z. Targoński, op. cit., 85.

8 Cf. W. Granat, Ku syntezie w definicji osoby, ZN KUL 3(1960)4, 22.

9 Cf. W. Granat, Personalizm chrześcijański. Teologia osoby ludzkiej, Poznań 1982, 576.

10 Cf. Cz. Bartnik, Dogmatyka katolicka, Lublin 2000, 362; Cf. K. Wojtyła, Osoba i czyn, in: Osoba i czyn oraz inne studia antropologiczne, ed. T. Styczeń, W. Hudy, J. Gałkowski, A. Rodziński, A. Szostek, Lublin 1994, 227-228. In regard to the integrity of a person in the context of acts and actions, the author points to the condition of a human as a person. He states that no phenomenological statement can reflect this unity, whereas it is fully perceivable based on action revealing the transcendency of a person and the perfection of the complexity of human nature. Ibid.

11 Cz. Bartnik, 362.
} 
(Johann Gottfried Herder); an animal suppressing its urges in pain (Sigmund Freud); a self-deluded animal (P. Ernst); a structural reflection of social awareness (Claude Levi-Strauss); existence that desires to become God (Jean-Paul Sartre); a being that finds itself in violence and blood (Friedrich Nietzsche); a conscious being towards death (Martin Heidegger); a creature of highest sexual deviancies (A. Moravia, J. Genet) ${ }^{12}$.

In reference to human nature, The Second Vatican Council affirms the third dimension, that is its integrality (cf. GS 14). One cannot underrate corporeality, because: "Though made of body and soul, man is one. Through his bodily composition he gathers to himself the elements of the material world; thus they reach their crown through him, and through him raise their voice in free praise of the Creator" (GS 14) ${ }^{13}$. At the same time, the constitution emphasizes that: "Now, man is not wrong when he regards himself as superior to bodily concerns, and as more than a speck of nature or a nameless constituent of the city of man" (GS 14). As the teachings of the Church assert, acknowledging mortality and spirituality of human soul elevates human beyond physical conditions. The spiritual dimension of human life allows individuals to reach the essence of themselves, as well as the essence of the realities around them ${ }^{14}$. Therefore, the concept of a man cannot be simply narrowed down to a sort of compilation of body and soul creating one substance.

When referring to the teachings of spiritual theologists, one needs to acknowledge that the soul is not limited in its reach to the concept of anima, that is animating the body. Instead, what is emphasized is its quality as spiritus allowing us to go beyond corporeality and sensuality. The autonomy of the spirit results in a purpose of man that cannot be resolved within the limits of human corporeality, e.g. the pursuit of truth, the desire for absolute goodness, happiness, etc. ${ }^{15}$ The separation of body and spirit purposes results in their being contradictory to each other (cf.: Rom 8:5; 8:10; 1Cor 2:11; Ga 5:17; 1Tes 5:23). This opposition is affected both by the difference in purposes, as well as by the laws each of them is ruled by. Hence, work on the sanctification of humans is about the integration of these two aspects on the basis of cooperation with God. Human beings in their corporeal and spiritual structure are capable of having a God ${ }^{16}$.

12 Ibid.

13 Cf. Ibid., 393-394; Cf. K. Wojtyła, op. cit., 236-238.

14 Cf. GS 14

15 Cf. A. Słomkowski, op. cit., 34.

16 Cf. Ibid., 35; A. Ruszała, Ze świętym Janem od Krzyża ku zjednoczeniu z Bogiem, Kraków 1999, 49. 
For John of the Cross, the idea of "body and soul" is the key issue in discussing the path to perfection. In fact, the idea has multiple references and interpretations, but most often it denotes a person. It is possible to define the scope of the word "soul" in John of the Cross's work that includes vegetal life and the seat of human desires. The notion of "spirit" means the rule of spiritual acts is not connected to the the vegetal aspect of life $^{17}$. Another interpretation of "spirit" was given by Sanson, and according to him the notion can be understood in a threefold way:

1. It is part of soul where powers reside, and hence it is a communication centre; 2. It is the space of receiving impulses that reach the soul;

3. It is a space connected to the activity of God who resides there and the activity of the soul striving for God under the influence of the Holy Spirit ${ }^{18}$.

For Saint John of the Cross the "soul-spirit" is the space for communication between human and God, and thereby the base for spiritual powers to act, such as: intellect, will and memory ${ }^{19}$.

When discussing the integrity of the human being, one needs to refer to the act of creation, in which man came into existence in body and spirit. This fact (cf. Gen 1:26-27) should be analysed with regard to the unity that touches upon the ontic relation to God. One might say man is "a total relation - a reference to God, His Nature (Essence) and to His Inner Being - to the Persons of the Holy Trinity." ${ }^{20}$ The image of human nature only gains its right form in respect to the "prototype image" according to which man was brought into existence. The characteristics of this relation was referred to in writings on human nature by Saint Irenaeus, Saint Athanasius of Alexandria and especially Saint Augustine ${ }^{21}$.

17 Cf. ibid., 63.

18 H. Sanson, El espińtu humano segun San Juan de la Cruz, Madrid 1962, 145-146.

19 A. Ruszała, op. cit., 64.

20 Cz. Bartnik, 393; A. Ruszała, op. cit., 49.

21 Cf. A. Słomkowski, op. cit., 35; L.A. Krupa, Obraz Boży w człowieku według nauki św. Augustyna, Lublin 1948; cf. GS 12. 